\title{
Scarcity of medium-sized phytoplankton in the northern Red Sea explained by strong bottom-up and weak top-down control
}

\author{
Ulrich Sommer* \\ Institut für Meereskunde, Düsternbrooker Weg 20, 24105 Kiel, Germany
}

\begin{abstract}
This study tested whether the extreme scarcity of larger nanophytoplankton and microphytoplankton in the Gulf of Aqaba and in the open northern Red Sea is caused by nutrient limitation or by selective removal by grazers. Samples of near surface phytoplankton were incubated on board under a fully factorial combination of release from grazing pressure and release from nutrient stress. Release from grazing pressure by different size classes was obtained by sieving through 100,20, and $10 \mu \mathrm{m}$ size mesh screens. Release from nutrient stress was obtained by enrichment of Si alone and a full enrichment by N, P, Si and trace elements. Growth rates of most phytoplankton taxa showed a strong, positive response to the full nutrient enrichment and a weaker, but significant response to grazer exclusion. Several diatom taxa showed a weak positive response to Si enrichment. Thus, bottom-up control of medium-sized algae appears to be more important than top-down control.
\end{abstract}

KEY WORDS: Phytoplankton · Red Sea $\cdot$ Nutrient limitation $\cdot$ Grazing $\cdot$ Bottom-up vs top-down control

\section{INTRODUCTION}

Phytoplankton in the extremely oligotrophic northern Red Sea, and in the Gulf of Aqaba (Klinker et al. 1978, Reiss \& Hottinger 1984), is characterized by a low biomass $\left(<0.8 \mathrm{mg}\right.$ chlorophyll $\left.\mathrm{l}^{-1}\right)$ dominated $(>95 \%)$ by phytoplankton $<5 \mu \mathrm{m}$ (Lindell \& Post 1995, Yahel et al. 1998). Only during the summer period does the large, nitrogen-fixing cyanobacterium Trichodesmium spp. also become prominent. Algae ranging from 5 to several $100 \mu \mathrm{m}$ are extremely scarce, though not totally absent (usually detectable only by plankton nets or by sedimentation of several $100 \mathrm{ml}$ of water, Kimor \& Goldanski 1992). During the stratified period, dissolved $N$ and $P$ are depleted below the detection limit (methods according to Strickland \& Parsons 1968), while remaining $\mathrm{Si}$ concentrations are low but still detectable (ca $0.5 \mu \mathrm{M}$ ). The resulting high Si: $N$ ratios make the scarcity of diatoms quite surprising (Sommer 1994a,b, 1996). It remains an open question as to whether the size structure and the taxonomic composi-

·E-mail: usommer@ifm.uni-kiel.de tion of the phytoplankton in the Gulf of Aqaba and the northern Red Sea can be explained by nutrient stress alone ('bottom-up' control) - or whether selective removal of medium-sized phytoplankton by herbivorous zooplankton ('top-down' control) might have some importance as well.

\section{METHODS}

The importance of nutrient stress versus grazing pressure was studied by ship-board (Meteor cruise 44-2; February 15 to March 19, 1999) 'release experiments' where algae were released from 1 or both control factors in a fully factorial combination of manipulations. The analysis of grazing in this study is focused on protozoan and naupliar grazing on nano- and microphytoplankton, while the grazing pressure by adult metazoa was studied by parallel investigations during the same cruise (Stibor \& Hansen unpubl.). Protozoan grazing on picoplankton $(<2 \mu \mathrm{m})$ was studied according to Landry's \& Hassetts's (1982) dilution technique by Berninger (unpubl.). 
Nutrient manipulations consisted of controls (no addition), silicate enrichment (4 $\mu \mathrm{M} \mathrm{Si})$ to release diatoms with high $\mathrm{Si}$ - but low $\mathrm{N}$ - and P-requirements from nutrient stress, and a full enrichment $(4 \mu \mathrm{M} \mathrm{Si}, 4.5 \mu \mathrm{M}$ $\mathrm{N}, 0.3 \mu \mathrm{MP}$ ) to release all phytoplankton from nutrient stress. Grazer manipulations consisted of sieving the sample through net-screens with the mesh sizes $100 \mu \mathrm{m}$ (removal of adult metazoa but not of protozoa and the smallest nauplii), $20 \mu \mathrm{m}$ (removal of larger protozoa) and $10 \mu \mathrm{M}$ (removal of medium-sized protoza). Protozoa $<10 \mu \mathrm{m}$ were not removed because they usually feed on pico- but not on nanoplankton and their removal would have also removed all of the target algae of this study.

The water samples for the experiments were taken from $10 \mathrm{~m}$ depth at stations in the Gulf of Aqaba (Expt 1: Stn 118, February 21, 28.582 ${ }^{\circ} \mathrm{N}, 34.651^{\circ} \mathrm{E}_{\mathrm{i}}$ Expt 4: Stn 152, March 2, 28.334 $\mathrm{N}, 34.551^{\circ}$ E) and 2 stations in the open Red Sea (Expt 2: Stn 132, February $24,27.298^{\circ} \mathrm{N}, 34.368^{\circ}$ E; Expt 3: Stn 145, February 27, $27.695^{\circ} \mathrm{N}, 34.670^{\circ} \mathrm{E}$ ) in order to compare phytoplankton from a deeply circulating water column (Gulf of Aqaba, $>300 \mathrm{~m}$ mixing depth) to phytoplankton from a stratified water column (Red Sea, mixing depth $<50 \mathrm{~m}$ ). This contrast in the mixing regime is quite typical for the study season, while summer stratification begins a few weeks later in the Gulf of Aqaba (WolfVecht et al. 1992, Genin et al. 1995). The manipulated water samples were incubated in 21 bottles floating in a deck incubator. Each treatment was duplicated in separate bottles. The deck incubator was cooled by a flowthrough of surface water $\left(21\right.$ to $\left.23^{\circ} \mathrm{C}\right)$ and shielded against direct sunlight by a cover which absorbed ca $70 \%$ of incident radiation.

Subsamples $(250 \mathrm{ml})$ were taken from the incubation bottles at Day 0, after Day 2, and after Day 5, preserved by Lugol's iodine for indentification at the genus level, and cell counts of the nano- and microplankton species were performed. The scarcity of nano- and microphy-

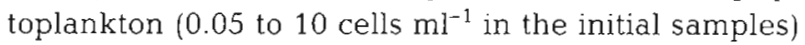
forced sedimentation of $200 \mathrm{ml}$ prior to microscopic counting in an inverted microscope. If cell numbers were sufficient, 100 individuals were counted per taxon, thus giving $95 \%$ confidence limits of ca $\pm 20 \%$ (Lund et al. 1958). However, in many cases counting of the entire counting chamber resulted in much lower numbers. The response of individual taxa to the experimental treatments was assessed by calculating net growth rates from the cell density data on Days 0 and 2. Net growth rates reflect the difference between rates of reproduction (controlled mainly by resources) and loss rates (mainly controlled by grazing in my experiments). The cell density could not be used as a response variable because sieving through plankton nets of different mesh size also changed the abun- dance of some phytoplankton taxa (shown for Rhizosolenia in Fig. 1). Protozoa were identified to larger functional groups and counted in a similar way to the phytoplankton. Nauplii were counted at the end of the experiments by sieving $1 \mathrm{l}$ through a $20 \mu \mathrm{m}$ screen.

The samples for Day 2 were expected to show the response of species which are relatively abundant and/or respond quickly to nutrient enrichment. The samples for Day 5 were expected to show the response of rare and/or slow-reacting species. However, the 2 to $5 \mathrm{~d}$ time interval was expected to be more strongly influenced by second-order effects than the 0 to $2 \mathrm{~d}$ time interval. Such second-order effects include the growth of microzooplankton released from predators, or larger competitors, and the growth of competing phytoplankton species.

Net growth rates were calculated from cell densities on Day $0\left(N_{0}\right)$ and Day $2\left(N_{2}\right)$ according to the equation

$$
\mathrm{r}=\left(\ln N_{2}-\ln N_{0}\right) / 2\left(\mathrm{~d}^{-1}\right)
$$

The significance of the growth rate response to the experimental treatments was tested by a 3-factor ANOVA (Statgraphics) with growth rates during the first $2 \mathrm{~d}$ as dependent variables and nutrient treatment (control, Si enrichment, full nutrient treatment), grazer exclusion (100, 20, and 10 um mesh size) and site (Gulf of Aqaba, open Red Sea) as main factors (Table 1). Pairwise interactions between the main factors were also tested. For the factors nutrient treatment and grazer exclusion, a multiple-range test based on least significant differences $(p<0.05)$ was performed in order to identify homogenous groups.

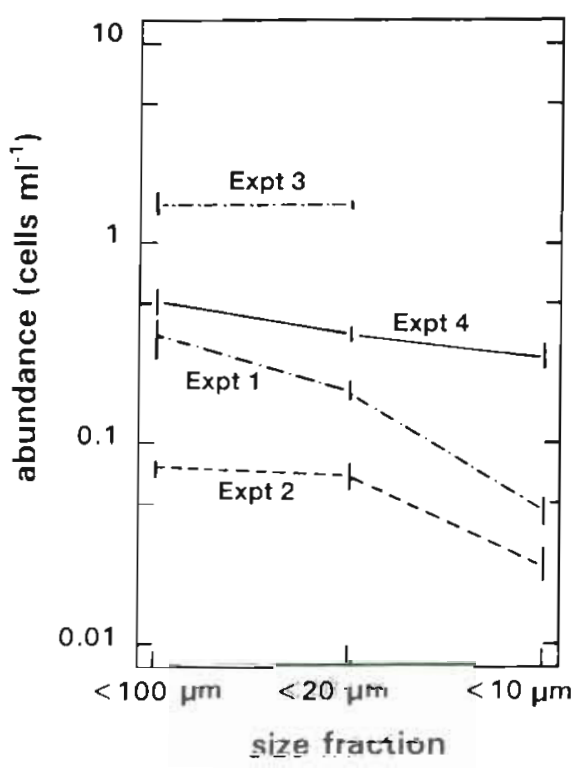

Fig. 1. Abundance of Rhizosolenia at the start of the experiments 
Table 1 . ANOVA of the phytoplankton growth rates with the main factors nutrients ( $N_{i}$ control, $\pm S i$, full enrichment), grazer exclusion $\left(G_{i}>100,>20\right.$, and $>10 \mu \mathrm{m}$ ) and site (S; Gulf of Aqaba, open Red Sea) and 2-factor interactions; Fratios and level of significance $\left({ }^{\prime} \cdot \mathrm{p}<0.0001_{i}{ }^{\cdots} \cdot \mathrm{p}<0.001 ;{ }^{\prime} \cdot \mathrm{p}<0.01_{i}{ }^{*} \mathrm{p}<\right.$ $0.05)$. SUD: small $(<10 \mu \mathrm{m})$, unidentified dinoflagellates. (-) Factor is irrelevant because the taxon has been present in only 1 size fraction or site

\begin{tabular}{|c|c|c|c|c|c|c|}
\hline Species & $N$ & $\mathrm{G}$ & S & $N \times G$ & $\mathrm{~N} \times \mathrm{S}$ & $\mathrm{G} \times \mathrm{S}$ \\
\hline Emiliana & $127.9 \cdots$ & $18.4^{\cdots}$ & - & 0.87 & - & - \\
\hline Gonyaulax & $15.5^{\cdots}$ & - & 2.64 & - & 0.19 & - \\
\hline SUD & $23.0 \cdots$ & $29.9^{\cdots}$ & 2.01 & 2.05 & 2.48 & 1.39 \\
\hline Gymnodinium & $17.9 \cdots$ & $5.06^{\circ}$ & $4.76^{\circ}$ & 0.35 & 0.38 & 0.93 \\
\hline Rhodomonas & $31.7 \cdots$ & $14.0^{\cdots}$ & 0.001 & 0.35 & 0.87 & 0.95 \\
\hline Pyraminonas & $15.7 \cdots$ & $5.71^{\cdots}$ & $8.87^{\cdots}$ & 0.19 & 0.005 & 0.041 \\
\hline Leptocylindrus & $117.1 \cdots$ & $8.04^{\cdots}$ & - & 0.019 & - & - \\
\hline Chaetoceros & $9.34 \cdots$ & - & 1.64 & - & 0.148 & - \\
\hline Thalassiosira & $35.3^{\cdots} \cdots$ & 3.87 & 1.84 & 1.81 & 0.73 & 0.61 \\
\hline Rhizosolenia & $158.8 \cdots$ & $24.2 \cdots$ & $7.44 \cdots$ & 1.68 & 2.82 & 0.23 \\
\hline Nitzschid & $102.2 \cdots$ & $10.1^{\cdots}$ & $20.9 \cdots$ & 0.36 & 2.44 & 0.75 \\
\hline Pseudonitzschia & $121.4^{\cdots} \cdot$ & $10.5^{\cdots}$ & $28.6^{\cdots \cdots}$ & 1.39 & $4.83^{\circ}$ & 0.27 \\
\hline Navicula & $48.8 \cdots$ & $42.5 \cdots$ & 0.98 & 0.31 & 1.40 & 0.72 \\
\hline
\end{tabular}

if the cell length of needle-shaped diatoms (Nitzschia spp., Navicula spp.) exceeded the mesh size.

\section{Time course of response}

No phytoplankton taxon could maintain the growth rate of the 0 to $2 \mathrm{~d}$ interval during the 2 to $5 \mathrm{~d}$ interval. Several even showed negative growth rates during the second interval. Decline of growth rates could be due to: (1) exhaustion of nutrients, even in the fully enriched bottles, or (2) growth of protozoa and subsequent increase in grazing losses. Both are second-order effects which do not reflect the controls of phytoplankton growth at the start of the incubation. Therefore, growth rates are only calculated for

\section{RESULTS}

\section{Effects of sieving on starting conditions}

Sieving through $100 \mu \mathrm{m}$ screens effectively removed adult metazoan zooplankton, but a small number of nauplii remained. Small copepodides which could have passed the $100 \mu \mathrm{m}$ screen were too rare to be found in the 21 bottles. The $20 \mu \mathrm{m}$ screens removed all nauplii and tintinnids. The ciliate Strombilidium spp. were either reduced or removed by the $20 \mu \mathrm{m}$ screen. Cell numbers of unidentified small athecate ciliates were almost unaltered in the $<20 \mu \mathrm{m}$ size fraction but were absent in the $<10 \mu \mathrm{m}$ fraction (Table 2). Heterotrophic nanoflagellates (HNF) had abundances of $160 \pm$ 70 cells $\mathrm{ml}^{-1}$ with no significant differences between size fractions and experiments (2-factor ANOVA; $p>$ 0.05). However, counts of Lugol's preserved cells with the inverted microscope provide almost certainly underestimates of HNF. Phytoplankton abundances were also influenced by sieving. Gonyaulax spp. and Chaetoceros spp. were absent in the $<10$ and $<20 \mu \mathrm{m}$ as Rhizosolenia spp. (Fig. 1), Leptocylindrus spp. (ca 15\% reduction by $20 \mu \mathrm{m}$ sieveing, $45 \%$ reduction by $10 \mu \mathrm{m}$ sieving), and Pseudonitzschia spp. (ca $20 \%$ reduction by $20 \mu \mathrm{m}$ sieving, $60 \%$ reduction by $10 \mu \mathrm{m}$ sieving) had significantly reduced abundances in the smaller size fractions (ANOVA; $\mathrm{p}<0.05$ ), while unicellular algae with a cell width smaller than the mesh size remained unaffected by sieving, even fractions. Chain-forming diatoms such the first interval. The second interval is only used to analyse the response of species which were below the detection limit at the start of the experiments. Abundances of nauplii, tintinnids and Strombilidium spp. remained constant during the 0 to $2 \mathrm{~d}$ interval, while 'undientified small ciliates' roughly doubled in the $<20 \mu \mathrm{m}$ fractions, with no significant differences between the different nutrient treatments $(p>0.05)$.

\section{Response of phytoplankton growth rates during the first interval}

Growth rates could be analysed for 13 phytoplankton taxa, which together formed more than $95 \%$ percent of the nano- and microphytoplankton biomass as estimated by cell volumes. Pairwise interactions between the main factors were generally insignificant. (Table 1), except for Pseudonitzschia and the combination Nutrients $\times$ Site. However, a Bonferroni-correction for 13 taxa would place also that interaction beyond the conventional significance limit of $p<0.05$. Nutri-
Table 2. Abundance of microzooplankton (ind. $\mathrm{l}^{-1}$ ) at the start of the experiments. First set of values: size fraction $<100 \mu m_{i}$ second value (where applicable): size fraction $<20 \mu \mathrm{m}$. USC: unidentified small ciliates

\begin{tabular}{|lcccc|}
\hline Group & Expt 1 & Expt 2 & Expt 3 & Expt 4 \\
\hline Nauplii & $11 \pm 4$ & $10 \pm 3$ & $18 \pm 5$ & $12 \pm 4$ \\
Tintinnidae & $20 \pm 7$ & $35 \pm 13$ & $25 \pm 8$ & $42 \pm 10$ \\
Strombilidium & $55 \pm 17$, & $33 \pm 8$ & $35 \pm 7$ & $13 \pm 3$ \\
USC & $12 \pm 3$ & & & \\
& $260 \pm 70$, & $315 \pm 35$, & $220 \pm 20$ & $100 \pm 25$ \\
& $310 \pm 130$ & $400 \pm 80$ & $170 \pm 30$ & $125 \pm 30$ \\
\hline
\end{tabular}




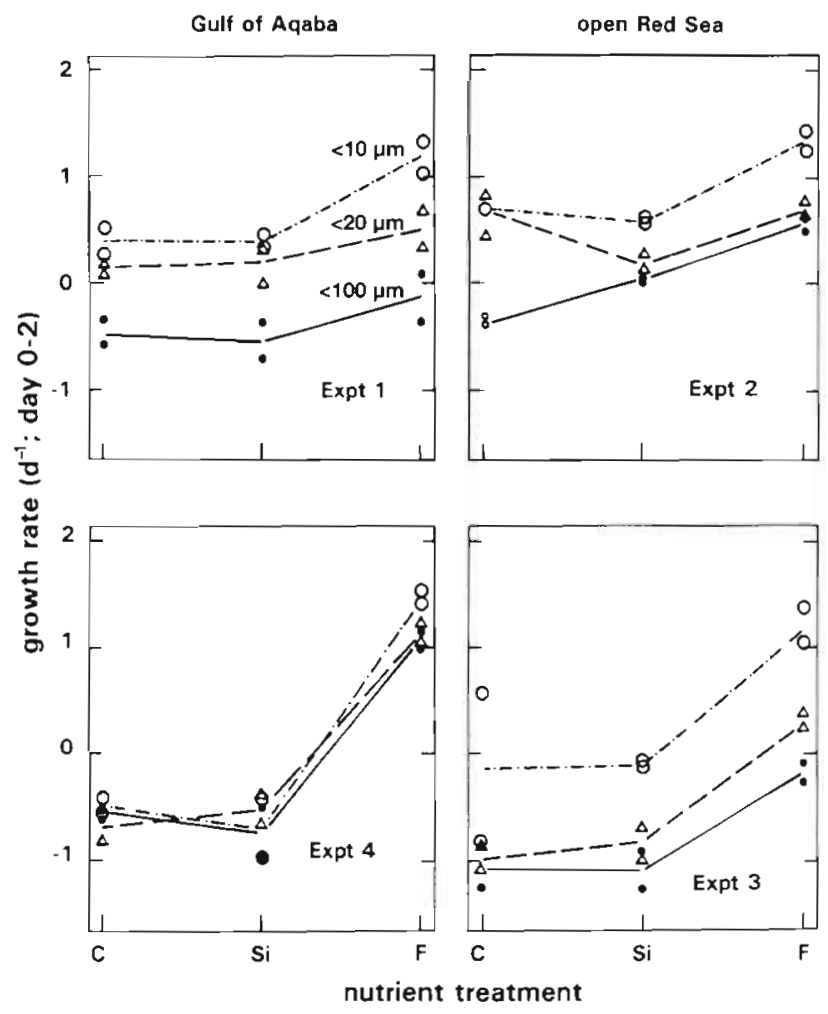

Fig. 2. Growth rates of Rhodomonas in response to the experimental treatments. C: no nutrient addition, Si: silicate enrichment, F: full nutrient enrichment (N, P, Si); (•) size fraction $<100 \mu \mathrm{m},(\Delta)$ size fraction $<20 \mu \mathrm{m},(0)$ size fraction $<10 \mu \mathrm{m}$

ents had highly significant effects on the growth rates of all taxa while grazer exclusion had significant effects on all but 1 taxon (the diatom Thalassiosira). Significant differences between both sites were found in less than half of the taxa.

The growth rates of non-siliceous algae (shown for Rhodomonas in Fig. 2) and of 3 diatoms (Chaetoceros, Leptocylindrus, Thalassiosira) responded only to the full nutrient enrichment but not to the Si enrichment, as indicated by controls and Si treatments forming 1 homogeneous group. The other diatoms (Rhizosolenia, Nitzschia, Pseudonitzschia, Navicula) responded to Si enrichment but the increase of growth rates was much smaller than the increase caused by a full nutrient enrichment (Figs. 3, 4 \& 5).

Most taxa responding to grazer exclusion exhibited increasing growth rates with decreasing mesh sizes used for zooplankton removal (Figs. 2 \& 5), except Pseudonitzschia (Fig. 3) for which no significant difference was found between the 10 and the $20 \mu \mathrm{m}$ treatments, and Leptocylindrus and Pyramimonas for which no difference appeared between the 20 and the $100 \mu \mathrm{m}$ treatments. Grazing effects could not be tested for Gonyaulax and Chatoceros because both were too large to pass the $20 \mu \mathrm{m}$ screen.

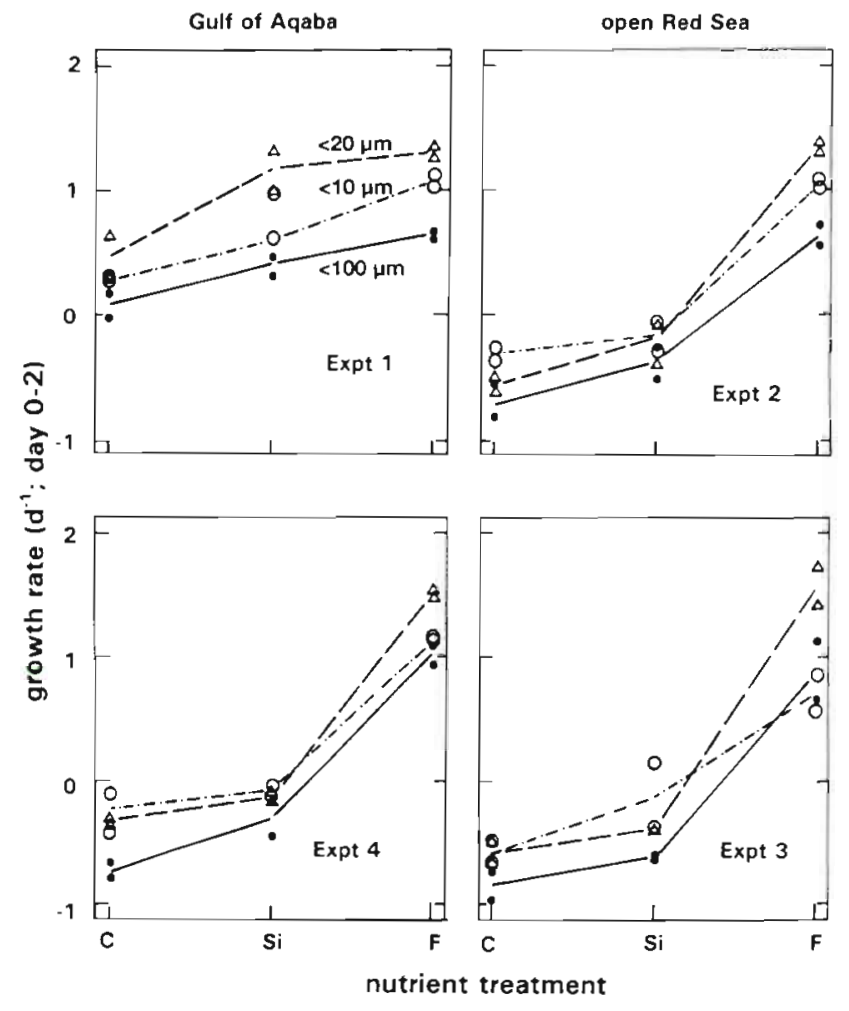

Fig. 3. Growth rates of Pseudonitzschia in response to the experimental treatments. $C$ : no nutrient addition, Si: silicate enrichments, F: full nutrient enrichment $(N, P, S i)$; $(\bullet)$ size fraction $<100 \mu \mathrm{m},(\Delta)$ size fraction $<20 \mu \mathrm{m},(0)$ size fraction $<10 \mu \mathrm{m}$

\section{Additional phytoplankton taxa after $5 \mathrm{~d}$}

Phytoplankton genera, which had been undetectable in the initial samples, did not appear in any of the unenriched bottles after $5 \mathrm{~d}$. The colonial diatom Thalassionema was found in 7 of the 8 Si-enriched $<100 \mu \mathrm{m}$ treatments and in 6 of the 8 fully enriched $<100 \mu \mathrm{m}$ treatments. Because of its size, it did not appear in the smaller size fractions. The dinoflagellate Ceratium was found in 5 of the 8 fully enriched $<100 \mu \mathrm{m}$ treatments. The smaller dinoflagellate Prorocentrum appeared in 6 of the 8 fully enriched $<100 \mu \mathrm{m}$ treatments and in all fully enriched $<20 \mu \mathrm{m}$ treatments. A similar pattern was found for the silicoflagellate Dictyocha (5 fully enriched $<100 \mu \mathrm{m}$ treatments, 7 fully enriched $<20 \mu \mathrm{m}$ treatments).

\section{DISCUSSION}

Dominance of picoplankton (usually defined as $<2 \mu \mathrm{m}$ ) or ultraplankton (defined as $<5$ or $<8 \mu \mathrm{m}$, depending on the author) is a frequently encountered phenomenon of extremely oligotrophic lakes and seas (Stockner \& Antia 1986, Li et al. 1993). The success of the smallest phyto- 


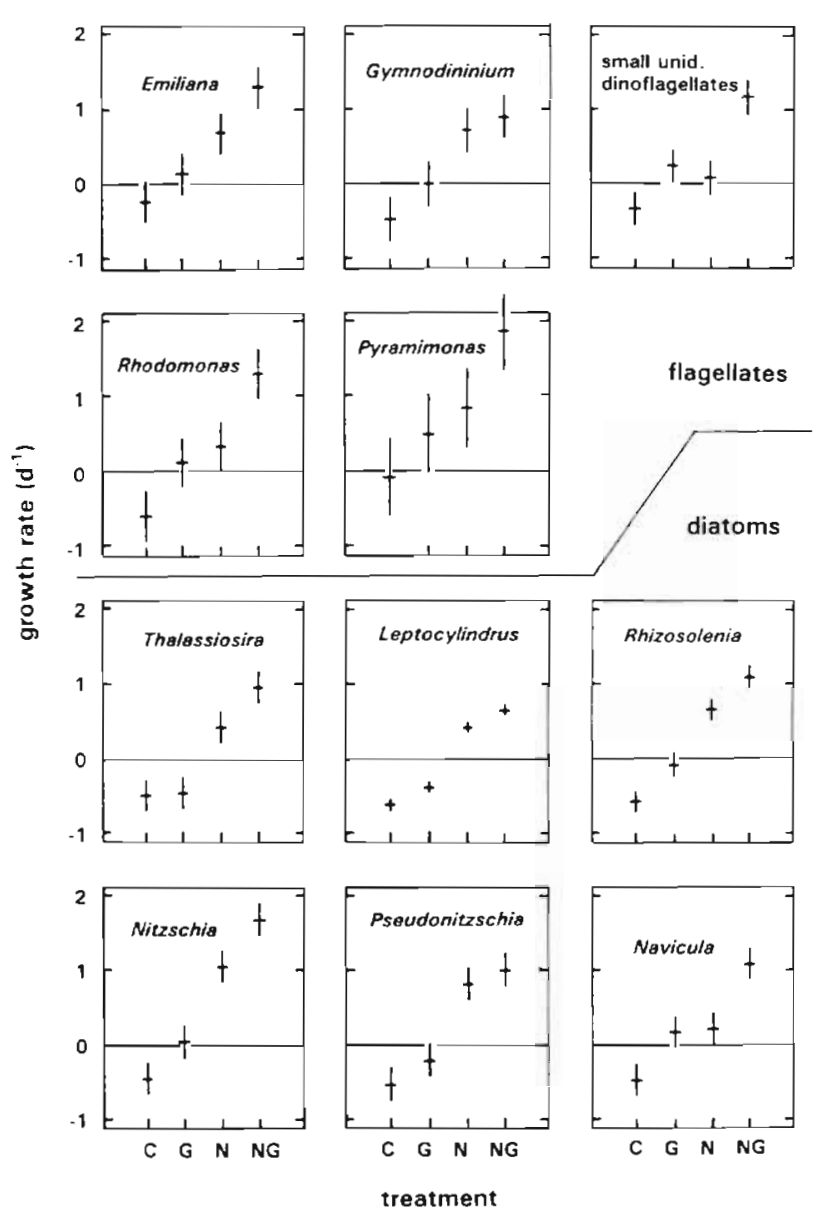

Fig. 4. Means and 95\% confidence limits of phytoplankton growth rates in controls $\left(C_{i}\right.$ no nutrient addition, size fraction $<100 \mu \mathrm{m}$ ); the most efficient grazer exclusion treatment $\left(\mathrm{G}_{i}\right.$ usually $<10 \mu \mathrm{m}$, in the case of Gymnodinium and Thalassiosira $<20 \mu \mathrm{m})$; the fully enriched nutrient treatment $(\mathrm{N})_{\text {; }}$ and the combined treatment with full nutrient enrichment and the most efficient grazer control (NG)

plankton size classes is frequently ascribed to their enhanced ability for retrieving mineral nutrients from a very dilute environment because of their favourable surface:volume ratio (Raven 1986). This study differs from most of the comparable studies on nutrient or other controls on phytoplankton growth by its focus. While it is common to ask about the controls on dominant taxa, here the question is focused on rare taxa: 'Why are medium-sized phytoplankton so scarce in the extremely oligotrophic Red Sea?'. It should be kept in mind that such a study is, by necessity, restricted to the moderately rare taxa, while it is impossible to draw conclusions on the causes for the rarity or absence of species which were below the detection limit. However, 17 genera from a wide array of higher taxa (Cryptophyta, Dinophyta, Prasinophyceae, Prymnesiophyceae, Bacillariophyceae) seem to be a sound basis for conclusions.

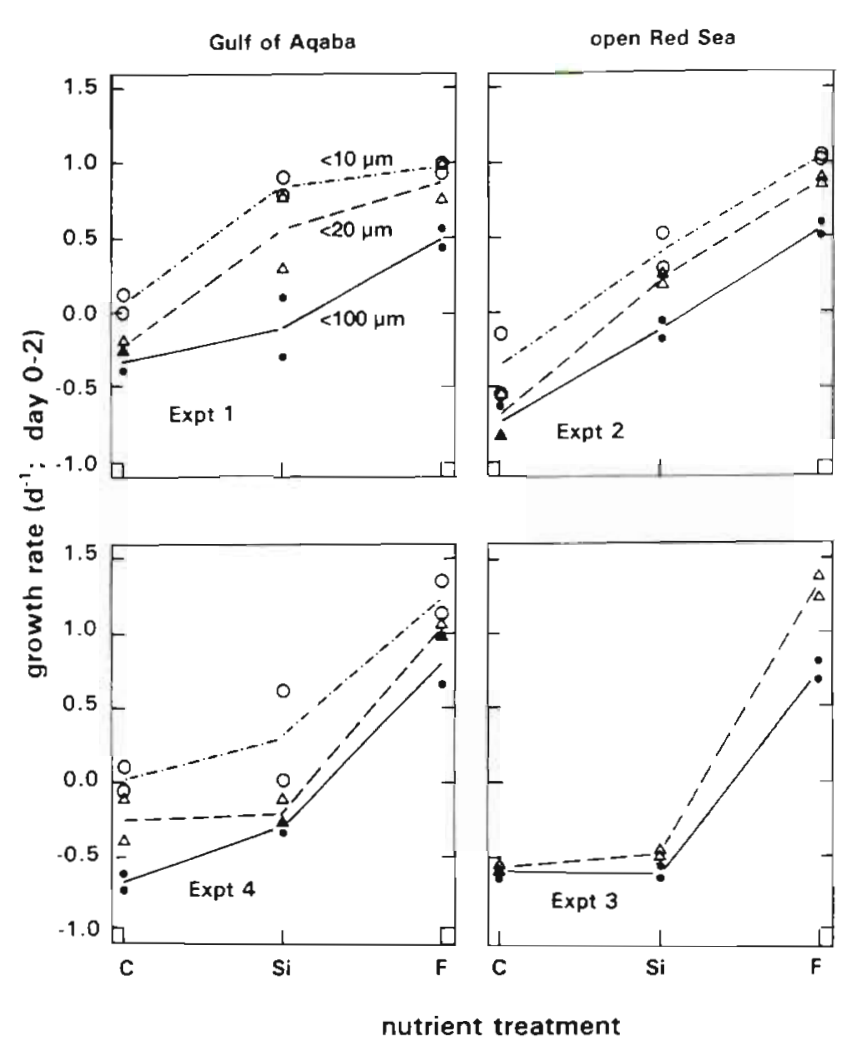

Fig. 5. Growth rates of Rhizosolenia in response to the experimental treatments: $\mathrm{C}$ : no nutrient addition, Si: silicate enrichment, $\mathrm{F}$ : full nutrient enrichment $(\mathrm{N}, \mathrm{P}, \mathrm{Si})$; $(\bullet)$ size fraction $<100 \mu \mathrm{m},(\Delta)$ size fraction $<20 \mu \mathrm{m},(0)$ size fraction $<10 \mu \mathrm{m}$

The control bottles (no enrichment, but $100 \mu \mathrm{m}$ filtration) in my experiments were not full controls because even in them phytoplankton were released from 2 potential limitations in situ: they were released from light limitation caused by deep vertical mixing (Sverdrup 1953), especially in the Gulf of Aqaba with $300 \mathrm{~m} \mathrm{mix-}$ ing depth, and from grazing by zooplankton $>100 \mu \mathrm{m}$. However, growth rates in the controls were either negative or not significantly different from zero (Fig. 4). Therefore, release from deep mixing and from grazing by mesozooplankton would not have been sufficient for permitting positive growth rates of medium-sized phytoplankton, even if those factors had contributed to their scarcity in situ. On the other hand, growth rates attained by the combination of a full nutrient enrichment and maximal grazer exclusion were not much lower than the maximal growth rates for phytoplankton of the nanoplankton and smaller microplankton size range reported in the literature (Schlesinger et al. 1981, Banse 1982), e.g. Rhizoselenia (15000 $\pm 34700 \mu \mathrm{m}^{3}$ cell volume) had growth rates of 0.9 to $1.3 \mathrm{~d}^{-1}$ at 21 to $23^{\circ} \mathrm{C}$, while Banse's equation for diatoms predicts a maximal growth rate of $1.32 \mathrm{~d}^{-1}$ at $20^{\circ} \mathrm{C}$. Therefore, it seems that the combination of a N+P+Si nutrient spike and of 
sieving out zooplankton $>10 \mu \mathrm{m}$ released the algae under study to a large extent from any factor which could have restricted growth, including adverse enclosure artifacts, grazing by nanozoplankton $<10 \mu \mathrm{m}$, unexplained sources of mortality (e.g. viruses), $N$ or $P$ competition by picophytoplankton and bacteria, or limitation by trace nutrients.

The relative importance of resource versus grazer control is one of the most frequently discussed questions in phytoplankton ecology. Obviously both are important, because the net growth rate is always the difference between the rates of reproduction and mortality. Nevertheless, a comparison of the nutrient effects and the grazer effects shows a clear hierarchy of factors in this study (Fig. 4). Grazing release alone was not sufficient to permit significantly positive growth rates of most taxa (exception: small, unidentified dinoflagellates). The full nutrient spike without grazing release permitted positive growth rates of 10 taxa (Gonyaulax, Chaetoceros, and 8 taxa shown in Fig. 4), it did not permit significantly positive growth rates of the small, unidentified dinoflagellates, Rhodomonas and Navicula.

The response of 4 diatom genera to Si enrichment was much weaker than the response to the full enrichment and did not lead to positive growth rates. Nevertheless, it seems to indicate that those diatoms were Silimited in situ. However, the nutrient status of these diatoms must have been so close to the transition between Si limitation and $\mathrm{N}$ or $\mathrm{P}$ limitation that $\mathrm{N}$ or $\mathrm{P}$ must have become limiting after even marginal growth initiated by $\mathrm{Si}$ addition. Si limitation in this environment is rather surprising, given the relatively high Si:N and Si:P ratios in the northern Red Sea (Si:N ca 1:1 during circulation and clearly >1:1 during stratification; Red Sea Program unpubl data) Members of 3 of the genera responding positively to Si had exhibited quite high optimal Si:N ratios in competition experiments performed in the Arabian Sea (Sommer 1998): Rhizosolenia optimal Si:N $=0.55: 1$; Pseudonitzschia 1:1; Nitzschia 5:1). Nutrient growth rate (Monod) curves for Si-limited diatoms frequently show a threshold concentration of Si (Paasche 1973). Such thresholds would make optimal Si:N or Si:P ratios the higher, the lower the nutrient concentrations are.

A dominance of nutrient control is no surprise in an ultraoligotrophic environment, although some authors have argued that phytoplankton in the oligotrophic ocean reproduce at nearly nutrient-saturated rates (Goldman et al. 1979). However, their inference was based on a C:N:P stoichiometry close to the Redfieldratio (106:16:1) for the entire seston. Such a bulk measurement may reflect the biomass composition of dominant phytoplankton species, but not the biomass composition of rare species which have been the focus of this study. If Goldman's assertion would apply to the Red Sea too, it might be argued that nutrient limitation could be the primary cause for the scarcity of mediumsized algae, while picoplankton obtain their dominance because of not being nutrient-limited. However, recent evidence of a high alkaline phosphatase activity associated to autotrophic picoplankton suggests P limitation in even the smallest phytoplankton species ( $\mathrm{Li}$ et al. 1998). In conclusion, scarcity of nutrients appears to be the single most important factor restricting the growth of medium-sized phytoplankton in the northern Red Sea. Note, that this study was performed just before the onset of summer stratification in the Gulf of Aqaba, and just after the onset of stratification in the open Red Sea, which implies that even more nutrient stress should be expected during the stratification period (Lindell \& Post 1995).

Acknowledgements. This study has been supported by the Deutsche Forschungsgemeinschaft (DFG) (support for the Meteor-cruise 44/2) and the Red Sea Programme of the Bundesministerium für Bildung und Forschung (BMBF).

\section{LITERATURE CITED}

Banse K (1982) Cell volumes, maximal growth rates of unicellülás algáe and ciliates, and the role of ciliates in the marine pelagial. Limnol Oceanogr 27:1059-1071

Genin A, Lazar B, Brenner S (1995) Vertical mixing and coral death in the Red Sea following the eruption of Mount Pinatubo. Nature 377:507-510

Goldman JC, MCCarthy JJ, Peavey DG (1979) Growth rate influence on the chemical composition of phytoplankton in oceanic waters. Nature 279:210-215

Kimor B, Goldansky B (1977) Microplankton of the Gulf of Elat: aspects of seasonal and bathymetic distribution. Mar Biol 41:55-67

Klinker J, Reiss Z, Kropach C, Levanon J, Harpaz H, Shapiro $Y\{1978\}$ Nutrients and biomass distribution in the Gulf of Aqaba (Elat), Red Sea. Mar Biol 45:53-64

Landry MR, Hassett RP (1982) Estimating the grazing impact of marine micro-zooplankton. Mar Biol 67:283-288

Li H, Veldhuis MJW, Post AF (1998) Alkaline phosphatase activities among planktonic communities in the northern Red Sea. Mar Ecol Prog Ser 173:107-115

Li WKW, Zohary T, Yacobi YZ, Wood AM (1993) Ultraphytoplankton in the eastern Mediterranean Sea: towards deriving phytoplankton from biomass flow cytometric measurements of abundance, fluorescence and light scatter. Mar Ecol Prog Ser 102:79-87

Lindell D, Post AF (1995) Ultraphytoplankton succession is triggered by deep winter mixing in the Gulf of Aqaba (Eilat), Red Sea. Liminol Oceanogr 40:1130-1141

Lund JWG, Kipling C, LeCren ED (1958) The inverted microscope method of estimating algal numbers and the statistical basis of estimations by counting. Hydrobiologia 11 : $143-170$

Paasche E (1973) Silicon and the ecology of marine plankton diatoms. I. Thalassiosira pseudonana (Cyclotella nand) grown in a chemostat with silicate as a limiling nutrient. Mar Biol 19:117-126

Raven JA (1986) Physiological consequences of extremely 
small size for autotrophic organisms in the sea. Can Bull Fish Aquat Sci 214:1-70

Reiss Z, Hottinger L (1984) The Gulf of Aqaba. Ecological micropaleontology. Springer Verlag, Berlin

Schlesinger DA, Molot LA, Shuter BJ (1981) Specific growth rates of freshwater algae in relation to cell size and light intensity. Can J Fish Aquat Sci 38:1052-1058

Sommer U (1994a) Are marine diatoms favoured by high Si:N ratios? Mar Ecol Prog Ser 115:309-315

Sommer U (1994b) The impact of light intensity and day length on silicate and nitrate competition among marine phytoplankton. Limnol Oceanogr 39:1680-1688

Sommer U (1996) Plankton ecology: the past two decades of progress. Naturwissenschaften 83:293-301

Sommer U (1998) From algal competition to animal produc-

Editorial responsibility: Otto Kinne (Editor)

Oldendorf/Luhe, Germany tion: enhanced ecological efficiency of Brachionus plicatilis with a mixed diet. Limnol Oceanogr 43:1393-1396

Stockner JG, Antia NJ (1986) Algal picoplankton from marine and freshwater ecosystems: a multidisciplinary perspective. Can J Fish Aquat Sci 43:2472-2503

Strickland JDH1, Parsons TR (1968) A practical handbook of seawater analysis. Bull Fish Res Board Can 169

Sverdrup HU (1953) On conditions for the vernal blooming of phytoplankton. J Cons Explor Mer 18:287-295

Wolf-Vecht A, Paldor N, Brenner S (1992) Hydrographic indications of advection/convection effects in the Gulf of Eilat. Deep-Sea Res 39:1393-1401

Yahel G, Post AF, Fabricius K, Marie KD, Vaulot D, Genin A (1998) Phytoplankton distribution and grazing near coral reets. Limnol Oceanogr 43:551-563

Submitted: September 15, 1999; Accepted: November 10, 1999 Proofs received from author(s): April 25, 2000 